\title{
Incorporation of Circular Aspects into Product Design and Labelling: Consumer Preferences
}

\author{
María D. Bovea ${ }^{1, *(1)}$, Valeria Ibáñez-Forés ${ }^{1}$, Victoria Pérez-Belis ${ }^{1}$, Pablo Juan ${ }^{2}$, \\ Marta Braulio-Gonzalo ${ }^{1}$ and Carlos Díaz-Ávalos ${ }^{3}$ \\ 1 Department of Mechanical Engineering and Construction, Universitat Jaume I, 12071 Castellón, Spain; \\ vibanez@uji.com (V.I.-F.); belis@uji.com (V.P.-B.); braulio@uji.com (M.B.-G.) \\ 2 Department of Mathematics, Universitat Jaume I, 12071 Castellón, Spain; juan@uji.com \\ 3 Department of Probability and Statistics, Universidad Nacional Autónoma de México, México \\ City 04510, Mexico; zhangkalo@gmail.com \\ * Correspondence: bovea@uji.es; Tel.: +34-964-728-112
}

Received: 24 April 2018; Accepted: 28 June 2018; Published: 4 July 2018

\begin{abstract}
The transition to a circular economy requires a fundamental change in products and the way they meet consumer demands. In this context, the aim of this article is to analyse the level of importance that consumers attach to the fact that circular aspects were incorporated into a product design and to the need to communicate them on the product labelling. The aspects analysed in this study are related to durability, repairability, recycled material content, low environmental impact, fair working conditions and origin. To this end, a survey was designed and conducted with a representative sample. It was found that Spanish consumers are concerned mainly about fair working conditions during the product manufacturing and the durability of the products. A high degree of congruence was found between the level of importance attached to incorporating each aspect into the product design and including this information in the product labelling. In addition, multinomial regression models are applied to identify the consumer profiles (gender, age, household size, level of education, household income) that are more or less prone to prefer products that incorporate these aspects into their design and labelling. Household size and gender are the socio-economic variables that most affect consumer preferences.
\end{abstract}

Keywords: circular economy; social; product requirement; consumer preference; statistics

\section{Introduction}

According to the World Business Council of Sustainable Development (WBCSD) [1], an increasing number of consumers are concerned about both the environmental impact of products and the social implications derived from their production, but still, it is unclear how relevant this group is and therefore how strong consumers support the respective environmental and social policies. From an environmental perspective, the product design framework is becoming increasingly oriented towards circular economy principles [2] to ensure that products, materials and resources remain in circulation for as long as possible, while reducing waste generation. From a social perspective, consumers are gradually more concerned about factors related to fair working conditions, use of local resources and recycled materials, etc. [3].

Circular economy principles encourage improvements to the design of products in order to ensure their durability, repairability, recycling, etc. and, in parallel, to promote local and fair jobs and opportunities for social integration [4]. This agrees with the sustainable development goals [5] which, among others, highlight that sustainable economic growth requires societies to create the conditions that allow people to have quality jobs that stimulate the economy, while not harming the 
environment. For this reason, it is mandatory that all these aspects are taken into account during the product design process. However, consumers play an important role in promoting sustainable consumption [6] and, therefore, demand products that incorporate such aspects. So it is necessary to know consumer preferences in order to consider them in the design process [7].

For example, more information about durability or extension of lifespan of some electrical and electronic equipment (EEE) are aspects in growing demand by consumers [8]. Therefore, it is important to ensure that strategies such as design for disassembly, design for repair and upgrades, etc., are taken into account during their design process [9]. As concluded by the Organization for Economic Cooperation and Development (OECD) [3] and WBCSD [1], consumers are increasingly concerned about environmental and social features of products and services in their everyday consumption decisions in an attempt to buy products manufactured using renewable energy, or refusing products manufactured under dubious working conditions. With this approach, it is important to also include design aspects which ensure that products are produced safely by workers, using local resources, etc. [10], since according to Hertel et al. [11] or Coelho [12] people are willing to pay more for goods produced under fair working conditions or for fair trade products, respectively.

Apart from the demand to incorporate these aspects into the product design process, today there is also a demand to include this information on product labelling. This key point has been recently highlighted by the Spanish Circular Economy Strategy [13], which promotes a responsible consumption model based on the transparency of information about product characteristics and their publicity on labels.

Porter [14] and Maurer and Pachl [9] have revealed considerable consumer interest in receiving information about the lifespan, repairability or upgradability of products, as well as costs and availability of spare parts. Along the same lines, information about characteristics related to the fair trade concept (e.g., fair working conditions, origin of resources, etc.) is also highlighted by De Pelsmacker and Janssens [15] as being demanded by consumers. A survey by the European Commission [16] and the European Economic and Social Committee [17] concluded that 92\% of respondents agreed to receive information about such aspects. Without such information, consumers are unable to reward manufacturers that produce long-lasting or repairable goods, or even those companies which respect workers' conditions or required resources.

One way to communicate all these aspects is through the information included on product labels. Previous research has demonstrated that consumers use product labelling when choosing a product [18] and it has been widely used by companies to differentiate their products from others [19].

In addition, some studies have analysed what motivates consumers or their preferences. Grunert et al. [20] and Schumacher [21] show that demand for product information depends on the specific consumer characteristics, whose preferences are influenced by their age, gender or level of education, among others [22-24].

Therefore, some effort should be made to understand the importance that consumers attach to the incorporation of circular aspects into products and to the need to communicate them on product labelling. By taking into account this context, the aim of this article is double. On the one hand, to analyse the level of importance that consumers attach to the fact that circular aspects were incorporated into a product design and to the need to communicate them on the product labelling. On the other hand, to identify the consumer profile who prefer that. This information can be useful for identifying focus audiences of future awareness campaigns in this area.

This paper is arranged as follows: a literature review, in which more demanded circular aspects are identified, is detailed in the next section, followed by a survey design and sample definition in Section 3, which allow us to know the importance attached by consumers to the identified circular aspects. Section 4 includes a statistical analysis where data are processed at different levels. Finally, Section 5 presents the discussion and conclusions. 


\section{Background}

A literature review was comprehensively carried out to identify the most relevant circular aspects demanded by consumers in product design and labelling. This was achieved by conducting research into papers published in the last decade in leading international journals indexed in recognised databases (e.g., Journal Citation Report, Scopus, etc.) and reports published by the European Commission about the needed, demanded or preferred aspects of the consumer products market. Note that the nomenclature of the considered aspects was unified to group the information provided by each analysed document.

Table 1 is a classification of the main literature published in recent years dealing with the research of circular aspects demanded when consumer purchase decisions are made. The following were identified for each study: the considered product, the general study aim (identifying design requirements, labelling study or consumer preferences assessment), the analysed circular aspects (environmental or social), the year and country where the study was conducted and, finally, the methodology applied to identify consumer demands.

As many authors have already pointed out, consumers are increasingly interested in the environmental and social criteria that must be taken into account when designing and/or labelling products as they tend to be more concerned about ethical causes [25-29]. The literature review shows that $56 \%$ of the reviewed studies identify both social and environmental aspects demanded by consumers when purchasing products. Although social concerns are increasing worldwide, as the increase of fair-trade markets demonstrates [30], literature continues being more concerned about environmental aspects than social ones, since $42 \%$ of the reviewed studies still focused only on environmental issues (see Table 1).

The commonest aspects found in the reviewed literature are those listed and defined as follows:

- Durability refers to a product's ability to maintain its functions over a prolonged time and the degree to which it is repairable before it becomes obsolete [31].

- Repairability refers to the ability and ease of a product to be repaired during its life cycle [32], including aspects related to its disassemblability or modulability.

- $\quad$ Recycled material content refers to the amount of product materials from secondary sources instead of raw/primary materials [33].

- Low environmental impact includes any aspect that contributes to reduce the environmental performance of a product during its life cycle. It considers both inputs and outputs of materials, energy, emissions or waste generated during the life cycle of products, measured in different impact categories [34,35].

- Fair working conditions includes indicators related to the characteristics of the work done in the product manufacturing stage, from raw material extraction activities to the distribution stage, such as workers' fair salary, hours worked, forced labour, gender discrimination, etc. [36].

- Origin of production is related to the distance from the product manufacturing location to the point of sale. This aspect is gaining importance internationally as "zero-mile" products are being considered an essential tool to fight against pollution by reducing the consumption of fossil fuels that result from transportation [37].

Low environmental impact is the most widely considered aspect in the literature (up to $81 \%$ of the reviewed studies). General ethical aspects and Fair working conditions are the second most considered (36\% and 28\%, respectively), followed by Durability, Recycled material content and Origin of production, all considered by around $20 \%$ of the reviewed studies. Reparability is the least addressed circular aspect $(14 \%)$.

Having analysed the aim of the reviewed studies, it can be stated that labelling is an important issue for consumer decisions on purchasing as $61 \%$ of the reviewed studies focus on this topic. Consumers often use the information found on packaging to evaluate purchased products' sustainability [27]. Many authors have identified a relation between socio-economic consumer 
characteristics and consumer attitudes towards labels [38-42]. However, some differences were identified when comparing the results of these studies, probably due to each study having a different niche market, as Park [26] previously pointed out. In line with this, when analysing the products on which the reviewed studies focused, only $6 \%$ of them focused on EEE, even though their usage has exponentially increased due to technological advances, and having become common in the daily lives of consumers and industries [43]. Generic or non-specified products were the most analysed ones ( $51 \%)$, followed by the food products considered by $26 \%$ of the reviewed studies, and the textile products considered by $11 \%$.

Most of the reviewed studies focused on European consumers, and only two analysed Spanish consumer preferences, and both focused on food products [20,44]. To explore these preferences, surveys and telephone/online questionnaires seemed the most appropriate techniques as they were the most widely used by researchers (up to $74 \%$ of the studies).

In this context, this study is focused on analyzing the Spanish consumer preferences of circular aspects, related to both design requirements and labelling of products. On the one hand, to foresee market demands and, on the other hand, to identify the socially and environmentally responsible practices that permeate consumer product marketing. This analysis should also include an in-depth study into how Spanish consumer socio-economic characteristics influence product purchase decisions. 
Table 1. Review of publications about the consumer product aspects demanded by the market.

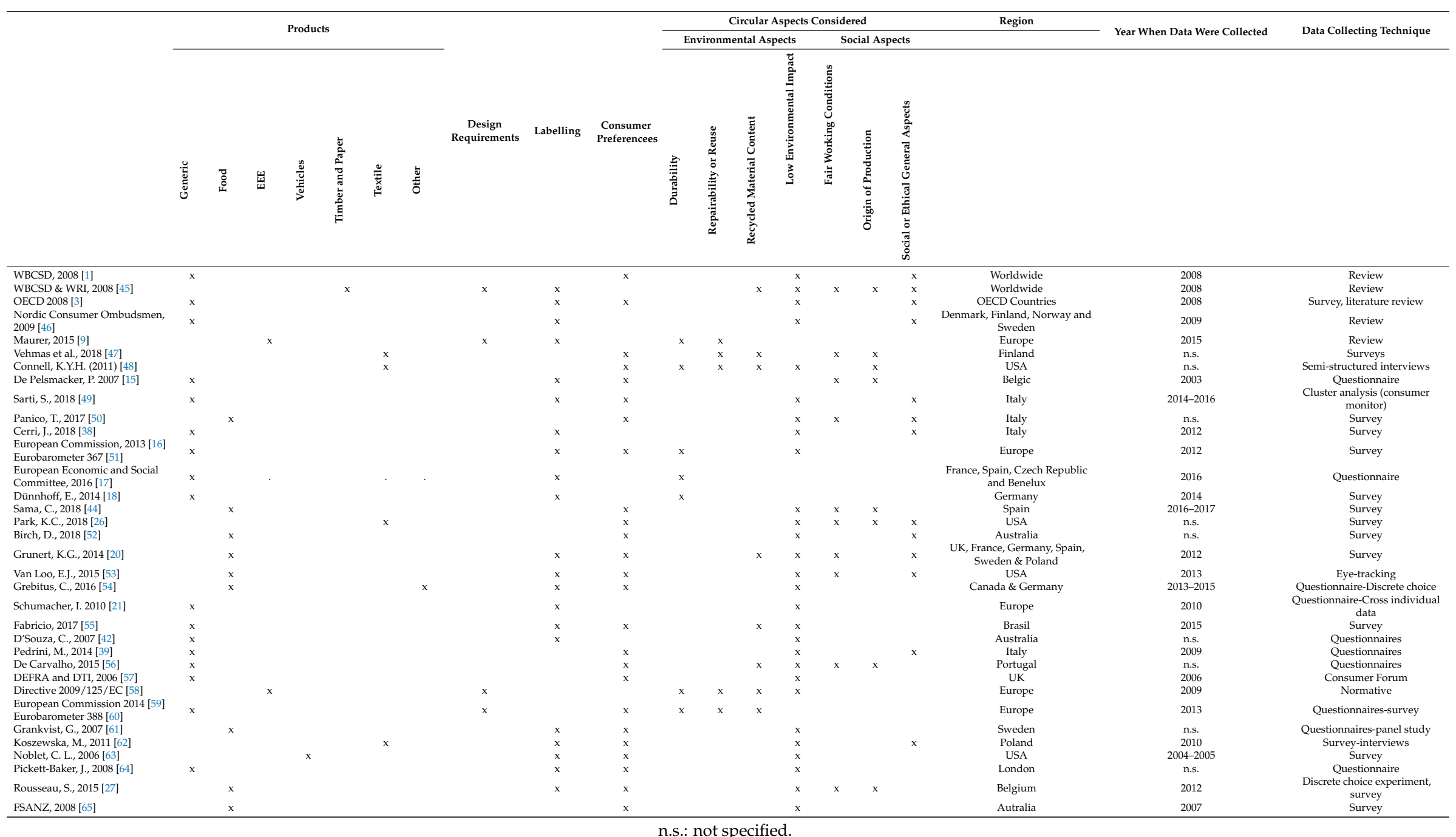




\section{Survey and Sample Definition}

A survey needs to be designed to understand the importance attached by consumers to considering the selected aspects related to the environmental and social performance of products during their design process, and to their communication on product labelling.

A survey was defined as Table 2 reports, bearing in mind the relevant aspects identified in the literature reviewed. On one hand, two response variables were proposed. The first was related to the importance that consumers attach to integrating the selected aspects into the design process. The second one was related to the importance conferred by consumers to include this information on the product labelling. All measurements were subjective assessments by the respondents using a rating scale. On the other hand, questions related to the socio-economic characteristics of respondents were included in the survey to identify the profile of consumers. Note that these questions form part of a more broader survey $[66,67]$.

Table 2. Questions and socio-economic variables included in the survey.

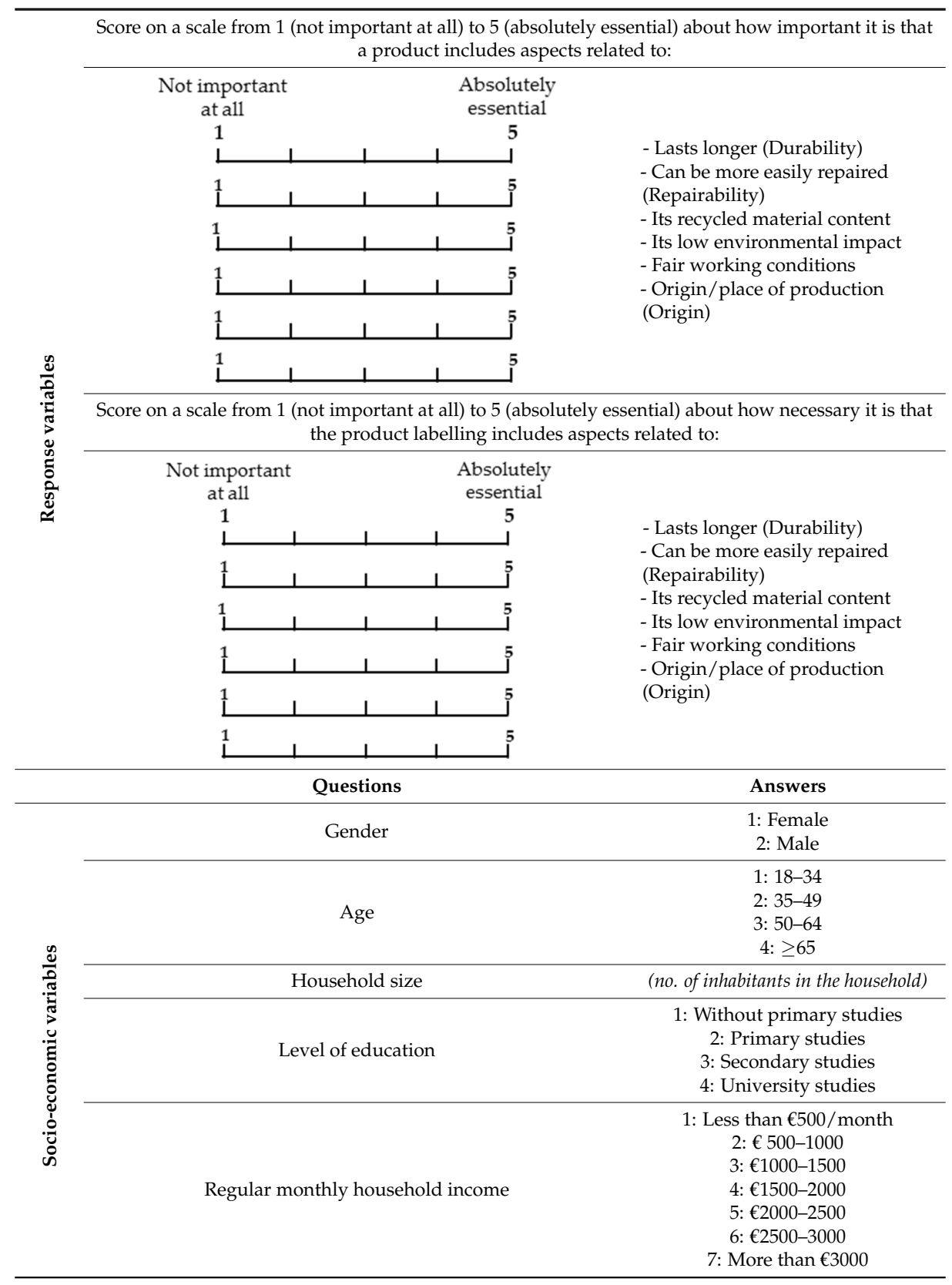


The method chosen to conduct the survey was telephone interviews carried out by a specialised company to guarantee high-quality answers and reliability throughout the process. Telephone surveys were conducted with inhabitants aged over 18 years in the city of Castellón de la Plana (Spain).

The methodology proposed by Bartlett et al. [68] was applied to calculate the required representative sample, according to Equation (1):

$$
n=\frac{(t)^{2} *(p)(1-p)}{(d)^{2}}
$$

where $n$ is sample size, $t$ is the $Z$ value for a specific confidence level, $p$ is the proportion of respondents who selected a specific choice, and $d$ is the confidence interval or margin of error.

By considering a $99 \%$ confidence level $(t=2.576)$, the maximum possible proportion of $50 \%$ $(p=0.5)$, which gives the largest sample size, and a $5 \%$ margin of error $(d=0.05)$, a minimum sample size of 663 respondents was obtained.

Table 3 shows the comparison between the distribution of the real characteristics of Castellón's population [69] (by gender and age) and the surveyed sample. This comparison ensures that the sample represents the study population's characteristics.

Table 3. Characteristics of both the population and sample.

\begin{tabular}{|c|c|c|c|c|c|c|}
\hline & \multicolumn{4}{|c|}{ Age Ranges } & & \\
\hline & $18-34$ & $35-49$ & $50-64$ & $>65$ & & \\
\hline & \multicolumn{6}{|c|}{ Population } \\
\hline Males & $\begin{array}{c}15,843 \\
(11.5 \%)\end{array}$ & $\begin{array}{c}22,557 \\
(16.3 \%)\end{array}$ & $\begin{array}{c}15,382 \\
(11.1 \%)\end{array}$ & 12,387 (9.0\%) & $\begin{array}{c}66,169 \\
(47.9 \%)\end{array}$ & 138,181 \\
\hline \multirow[t]{2}{*}{ Females } & $\begin{array}{c}16,303 \\
(11.8 \%)\end{array}$ & $\begin{array}{c}22,376 \\
(16.2 \%)\end{array}$ & $\begin{array}{c}16,625 \\
(12.0 \%)\end{array}$ & $\begin{array}{c}16,708 \\
(12.1 \%)\end{array}$ & $\begin{array}{c}72,012 \\
(52.1 \%)\end{array}$ & $(100 \%)$ \\
\hline & \multicolumn{6}{|c|}{ Sample } \\
\hline Males & $11.5 \%$ & $16.3 \%$ & $11.3 \%$ & $9.0 \%$ & $48.0 \%$ & \\
\hline Females & $11.8 \%$ & $16.3 \%$ & $12.0 \%$ & $12.0 \%$ & $52.0 \%$ & $100 \%$ \\
\hline
\end{tabular}

\section{Statistical Analysis of the Results}

\subsection{Descriptive Analysis of the Survey Responses}

A descriptive analysis was performed for the responses obtained for each question (response variable). In addition, contingency tables were obtained and allowed to explore whether or not the responses to different questions are independent of each other. To this end, independence tests such as X-squared were applied.

The importance that survey respondents attached to the first response variable reported in Table 2, "Incorporation of different aspects into product design", is shown in Figure 1a. We can see that the level of importance depends largely on the aspect. Fair working conditions came over as being absolutely essential $(67.0 \%)$ or very important $(29.0 \%)$ for $96.0 \%$ of the respondents, while Durability came over as being absolutely essential (60.8\%) or very important (19.0\%) for $79.8 \%$ of them. Origin, although by far the third most rated aspect, is considered absolutely essential (15.8\%) or very important (31.7\%) by $47.5 \%$ of the respondents. The remaining aspects analysed, Low environmental impact, Recycled material content and Repairability, were poorly rated by those surveyed, and only 33.8\%, 32.2\% and $29.3 \%$ of the respondents, respectively, considered them absolutely essential or very important to be included in product designs.

Regarding the second response variable, "The importance that respondents attached to the need to incorporate information about the previous aspects on product labelling", Figure $1 \mathrm{~b}$ shows, once 
again, that the importance level depends largely on the aspect. In this case, Fair working conditions is, by far, the most demanding aspect to appear on labelling. For $94.4 \%$ of the respondents, this aspect should be included on product labelling in an absolutely essential way $(68.1 \%)$ or in a very important way $(26.4 \%)$. Durability is the second most rated aspect, considered absolutely essential $(40.2 \%)$ or very important $(22.8 \%)$ by $63.0 \%$ of the respondents. The remaining aspects analysed, Origin, Recycled material content, Low environmental impact and Repairability, were poorly rated by the surveyed individuals, and only $45.7 \%, 41.0 \%, 39.8 \%$ and $31.0 \%$ of them, respectively, considered them absolutely essential or very important to be included on product labelling.

(a) Product design aspect

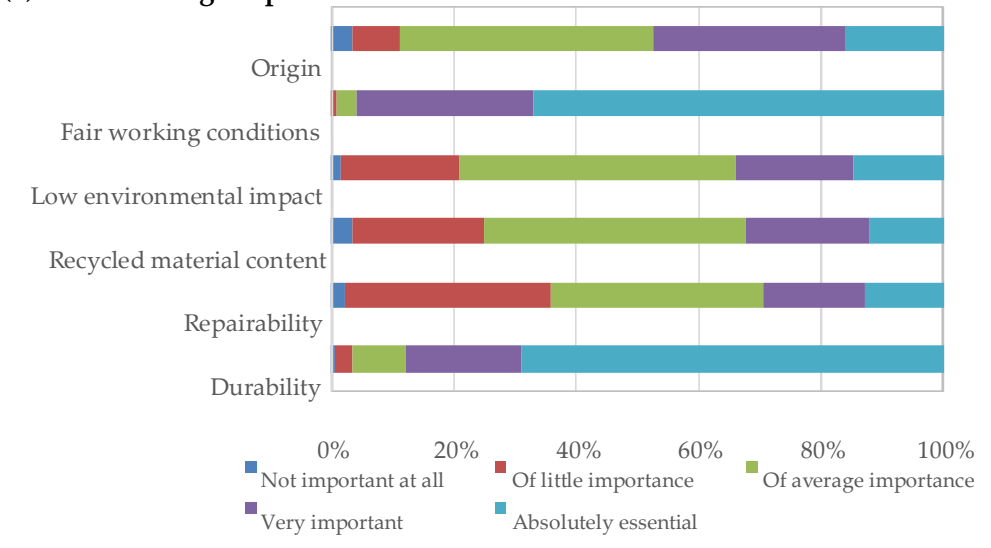

(b) Aspect on labelling

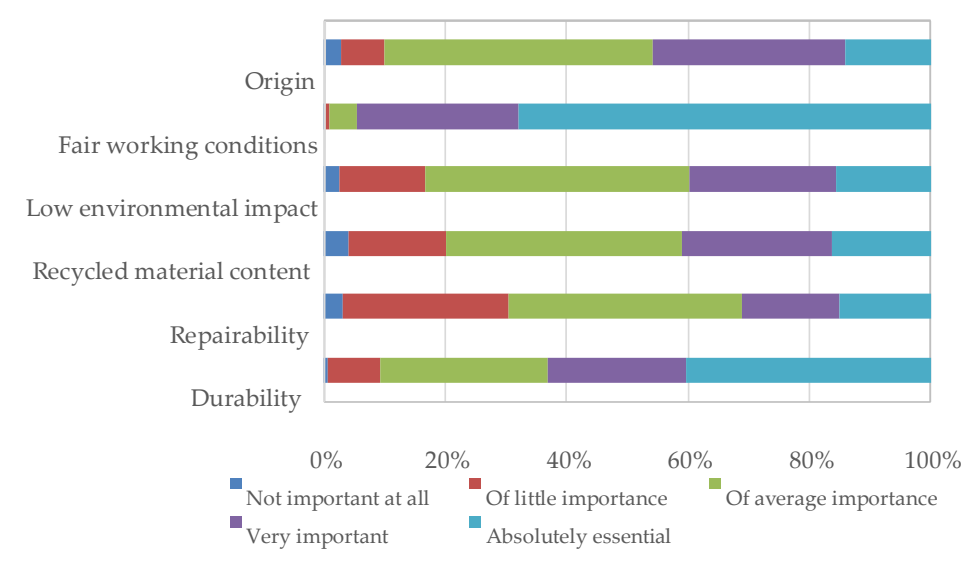

Figure 1. Importance attached by consumers.

It is also interesting to assess the possible relationship between the importance placed on incorporating a certain aspect into a product design by respondents and the importance given to including the same aspect on product labelling. The association between these two answers can be made by means of contingency tables (Table 4 ).

For each table, higher values at or near the main diagonal imply a close association between the importance conferred on incorporating an aspect into a product design and the importance of including the same aspect on product labels. This is analogous to a high correlation between these two variables. Larger numbers off the diagonal mean lack of association between variables. 
Table 4. Contingency tables.

\begin{tabular}{|c|c|c|c|c|c|c|c|c|c|c|c|c|c|c|c|c|c|c|c|c|}
\hline & \multicolumn{6}{|c|}{ Durability } & \multicolumn{8}{|c|}{ Repairability } & \multicolumn{6}{|c|}{$\begin{array}{c}\text { Recycled Material } \\
\text { Content }\end{array}$} \\
\hline & \multicolumn{6}{|c|}{$\begin{array}{c}\text { Importance of } \\
\text { aspect on product labelling }\end{array}$} & \multicolumn{8}{|c|}{$\begin{array}{l}\text { Importance of aspect on } \\
\text { product labelling }\end{array}$} & \multicolumn{6}{|c|}{$\begin{array}{l}\text { Importance of aspect on } \\
\text { product labelling }\end{array}$} \\
\hline \multirow{6}{*}{$\begin{array}{l}\text { Importance of } \\
\text { aspect in a } \\
\text { product design }\end{array}$} & & 1 & 2 & 3 & 4 & 5 & \multirow{6}{*}{$\begin{array}{l}\text { Importance of } \\
\text { aspect in a } \\
\text { product design }\end{array}$} & & 1 & 2 & 3 & 4 & 5 & \multirow{6}{*}{$\begin{array}{l}\text { Importance of } \\
\text { aspect in a } \\
\text { product design }\end{array}$} & & 1 & 2 & 3 & 4 & 5 \\
\hline & 1 & 3 & 0 & 0 & 0 & 1 & & 1 & 2 & 5 & 4 & 0 & 1 & & 1 & 11 & 1 & 1 & 4 & 4 \\
\hline & 2 & 2 & 13 & 3 & 0 & 1 & & 2 & 13 & 112 & 46 & 14 & 13 & & 2 & 1 & 65 & 22 & 20 & 11 \\
\hline & 3 & 0 & 5 & 35 & 8 & 6 & & 3 & 4 & 33 & 135 & 22 & 17 & & 3 & 7 & 18 & 149 & 45 & 25 \\
\hline & 4 & 0 & 15 & 20 & 75 & 11 & & 4 & 1 & 10 & 26 & 48 & 11 & & 4 & 3 & 6 & 34 & 62 & 16 \\
\hline & 5 & 0 & 23 & 110 & 67 & 245 & & 5 & 0 & 7 & 11 & 8 & 48 & & 5 & 0 & 3 & 14 & 15 & 40 \\
\hline X-squared & \multicolumn{6}{|c|}{602.16} & \multicolumn{8}{|c|}{396.23} & \multicolumn{6}{|c|}{453.98} \\
\hline \multirow[t]{4}{*}{$p$-value } & \multicolumn{6}{|c|}{$2.2 \times 10^{-16}$} & \multicolumn{8}{|c|}{$2.2 \times 10^{-16}$} & \multicolumn{6}{|c|}{$2.2 \times 10^{-16}$} \\
\hline & \multicolumn{6}{|c|}{$\begin{array}{l}\text { Low Environmental } \\
\text { Impact }\end{array}$} & \multicolumn{8}{|c|}{ Fair working Conditions } & \multicolumn{6}{|c|}{ Origin of Production } \\
\hline & \multicolumn{6}{|c|}{$\begin{array}{l}\text { Importance of aspect on } \\
\text { product labelling }\end{array}$} & \multicolumn{8}{|c|}{$\begin{array}{l}\text { Importance of aspect on } \\
\text { product labelling }\end{array}$} & \multicolumn{6}{|c|}{$\begin{array}{l}\text { Importance of aspect on } \\
\text { product labelling }\end{array}$} \\
\hline & & 1 & 2 & 3 & 4 & 5 & \multirow{6}{*}{$\begin{array}{l}\text { Importance of } \\
\text { aspect in a } \\
\text { product design }\end{array}$} & & 1 & 2 & 3 & 4 & 5 & \multirow{6}{*}{$\begin{array}{l}\text { Importance of } \\
\text { aspect in a } \\
\text { product design }\end{array}$} & & 1 & 2 & 3 & 4 & 5 \\
\hline \multirow{5}{*}{$\begin{array}{l}\text { Importance of } \\
\text { aspect in a } \\
\text { product design }\end{array}$} & 1 & 2 & 0 & 0 & 2 & 4 & & 1 & 0 & 0 & 0 & 0 & 0 & & 1 & 20 & 0 & 2 & 0 & 0 \\
\hline & 2 & 2 & 47 & 19 & 24 & 9 & & 2 & 0 & 4 & 0 & 0 & 2 & & 2 & 0 & 46 & 4 & 0 & 0 \\
\hline & 3 & 3 & 16 & 179 & 44 & 13 & & 3 & 0 & 0 & 18 & 0 & 2 & & 3 & 0 & 0 & 282 & 0 & 0 \\
\hline & 4 & 4 & 11 & 28 & 58 & 14 & & 4 & 2 & 0 & 4 & 190 & 14 & & 4 & 0 & 0 & 0 & 212 & 0 \\
\hline & 5 & 1 & 1 & 22 & 12 & 52 & & 5 & 0 & 0 & 8 & 0 & 472 & & 5 & 0 & 0 & 5 & 0 & 94 \\
\hline X-squared & \multicolumn{6}{|c|}{374.06} & \multicolumn{8}{|c|}{744.22} & \multicolumn{6}{|c|}{1234.2} \\
\hline$p$-value & \multicolumn{6}{|c|}{$2.2 \times 10^{-16}$} & & & & $.2 \times$ & $10^{-16}$ & & & & & & $2 \times$ & $10^{-16}$ & & \\
\hline
\end{tabular}

To interpret the results in each contingency table, it is necessary to observe the location of the responses in the table. Many responses on the diagonal mean a high congruence level since respondents attach the same level of importance to incorporating a certain aspect into a product design and to including this aspect on product labelling. If many responses appear at the top of the diagonal, respondents attach less importance of incorporating the aspect into the product design and on product labelling. On the contrary, if many responses appear at the bottom of the diagonal, the level of importance is high for both response variables. In addition, many responses below the main diagonal in the contingency table means that including a certain aspect on product labelling is regarded as less important than incorporating it into the product design. Finally, many responses above the main diagonal means that incorporating a certain aspect into the product design is regarded as less important than including it on product labelling.

Three different patterns can be observed in the contingency tables reported in Table 4:

- The contingency tables for aspects related to Repairability, Recycled material content and Low environmental impact show a large number of responses on the main diagonal (57-60\% of the responses), with a larger number of responses in the central part of the diagonal, while 22-26\% of the responses are grouped above the main diagonal and 18-19\% of them below the diagonal. This means that slightly more than half of the respondents attach the same level of importance to incorporating each aspect and to including them on product labelling by assigning an average level of importance, range from 3.1 to 3.3, depending on the aspect (scale from 1 to 5). Of those remaining, slightly more than a half prioritise labelling as opposed to design.

- The contingency tables for Durability also show many responses on the main diagonal $(58 \%$ of the responses), with more responses in the lower part of the diagonal; $4 \%$ of the responses are grouped above the main diagonal and $38 \%$ of them below the diagonal. This means that nearly $60 \%$ of the respondents attach the same level of importance to incorporating each aspect and to including them on product labelling by assigning an average level of importance (4.5). Of those remaining, almost the whole sample prioritises the incorporation of the given aspect during product design as opposed to including this aspect on product labelling.

- The contingency table for Fair working conditions and Origin show practically all the responses on the main diagonal ( $96 \%$ and $99 \%$, respectively), with more responses at the bottom of the diagonal for the aspect Fair working conditions, and in the middle-lower area for Origin. The percentage of 
responses grouped above or below the main diagonal is around $0-2 \%$. This means that almost all the respondents attach the same level of importance to incorporating each aspect and including them on product labelling by attaching an average level of importance (4.7) for Fair working conditions and 3.5 for Origin.

In addition, $\mathrm{X}$-squared independence test analyses were performed to statistically corroborate the independence among responses. For this purpose, the Generalized Linear Interactive Modelling (GLIM) package in $\mathrm{R}$ was applied to compute the deviances and the $p$-values for the different cross independence tests [70]. As $p$-values are lower than 0.05 in all cases, it can be concluded that the hypothesis of independence between aspects in the product and aspects on labelling should be rejected, which implies a statistically significant association between those variables.

\subsection{Multinomial Regression}

Multinomial regression models are applied to identify the consumer profiles that are more or less prone to prefer products that incorporate the previously analysed aspects into their design and labelling.

Multinomial regression coefficients are interpreted as the rate of change in the logarithm of the probability at level $\mathrm{k}(k=2, \ldots, n)$ against level 1 , which is considered a reference level, according to Equation (2):

$$
\log \left[\frac{p_{k}}{p_{1}}\right]=X \beta
$$

where $X$ represents the design matrix whose entries are the values of the socio-economic variables, and $\beta$ represents the regression coefficients. These regression coefficients measure the linear effect on the logarithm of the proportion of probabilities. The general model structure is shown in Equation (3):

$$
Y_{i}=\beta_{0}+\sum_{i} \beta_{i} X_{i}
$$

where $Y_{i}$ represents each response variable, $\mathrm{Xi}$ denotes each socio-economic variable, $\beta_{0}$ is a scalar that represents the intercept, and $\beta_{i}=\left(\beta_{1}, \ldots, \beta_{M}\right)$ are the coefficients of the linear effects of each socio-economic variable $X_{i}$.

Thus the model shown in Equation (3) fitted all the response variables, using the sample's representative socio-economic characteristics results obtained from the survey and presented as follows in Table 5 as explanatory factors.

Table 5. Descriptive statistics of the sample's socio-economic characteristics.

\begin{tabular}{ccc}
\hline Independent Variables & Scale & Proportion of the Total (\%) \\
\hline \multirow{2}{*}{ Gender } & 1: Female & 48.0 \\
& $2:$ Male & 52.0 \\
\hline \multirow{2}{*}{ Age } & $1: 18-34$ & 23.3 \\
& $2: 35-49$ & 32.5 \\
& $3: 50-64$ & 23.3 \\
Level of education & $4: \geq 65$ & 21.0 \\
& 1: Incomplete primary education & 1.4 \\
& 2: Primary education & 13.5 \\
& 3: Secondary education & 47.6 \\
4: University Studies & 35.6 \\
& 99: do not answer/do not know & 1.9 \\
\hline & 1: one person & 6.8 \\
& 2: two people & 28.3 \\
3ousehold size & 3: four people & 30.3 \\
& 5: five people & 27.5 \\
& 6: six people & 6.1 \\
& 7: seven people & 1.0
\end{tabular}


Table 5. Cont.

\begin{tabular}{ccc}
\hline Independent Variables & Scale & Proportion of the Total (\%) \\
\hline & 1: less than $€ 500 /$ month & 6.8 \\
& 2: $€ 500-1000$ & 12.8 \\
3: $€ 1000-1500$ & 19.5 \\
Level of family income & 4: $€ 1500-2000$ & 17.3 \\
& 5: $€ 2000-2500$ & 11.0 \\
6: $€ 2500-3000$ & 11.4 \\
& 7: more than $€ 3000$ & 10.0 \\
99: Do not know & 11.4 \\
\hline
\end{tabular}

The multinomial regression model structure is presented in Figure 2 for each response variable. A socio-economic variable $X_{i}$ has a significant effect on response variable $Y_{i}$ if its corresponding regression coefficient $\beta_{i}$ is more than twice its standard deviation value. The positive sign of the corresponding $\beta_{i}$ implies that the response variable increases when the socio-economic variable increases. The higher the coefficient $\beta_{i}$, the stronger the effect of this socio-economic variable will be.

The analyses were carried out with the freeware statistical package $R$ (version 3.1) [71].

Response variables
\begin{tabular}{|l|r|}
\hline - Importance attached by consumers to incorporate circular aspects into the product design \\
- Importance attached by consumers to include circular aspects on product labelling & $\begin{array}{r}\text { Gender } \\
\text { Age }\end{array}$ \\
\hline Response variable $=\beta_{0}+\beta_{1}$ gender $+\beta_{2}$ age $+\beta_{3}$ level of education $+\beta_{4}$ household size $+\beta_{5}$ household income \\
\hline
\end{tabular}

Figure 2. The multinomial regression model structure.

Table 6 shows the results of the statistical models for the first response variable "Importance attached by consumers to incorporating circular aspects into the product design".

Table 6. Multinomial regression model for the "Importance attached by consumers to incorporating circular aspects into the product design" (mean [SD]).

\begin{tabular}{|c|c|c|c|c|c|c|}
\hline & & $\beta_{1}$ Gender & $\beta_{2}$ Age & $\begin{array}{l}\beta_{3} \text { Level of } \\
\text { Education }\end{array}$ & $\begin{array}{c}\beta_{4} \text { Household } \\
\text { Size }\end{array}$ & $\begin{array}{l}\beta_{4} \text { Household } \\
\text { Income }\end{array}$ \\
\hline \multirow{4}{*}{ Durability } & 2 & $-0.442[1.042]$ & $0.31131[0.59390]$ & $-0.063[0.214]$ & $-0.084[0.508]$ & $-0.11457[0.24073]$ \\
\hline & 3 & $0.659[0.956]$ & $0.36996[0.56058]$ & $0.064[0.197]$ & $-0.296[0.474]$ & $-0.03293[0.22515]$ \\
\hline & 4 & $0.574[0.937]$ & $0.66102[0.55116]$ & $-0.068[0.194]$ & $-0.061[0.463]$ & $-0.15743[0.22017]$ \\
\hline & 5 & $0.472[0.925]$ & $0.53578[0.54534]$ & $-0.003[0.190]$ & $-0.148[0.457]$ & $-0.07701[0.21709]$ \\
\hline \multirow{4}{*}{ Repairability } & 2 & $-0.232[0.564]$ & $0.35253[0.27160]$ & $0.17143[0.13014]$ & $0.62202[0.29606]$ & $-0.02797[0.14134]$ \\
\hline & 3 & $-0.328[0.563]$ & $0.16666[0.27101]$ & $0.15094[0.12983]$ & $0.61411[0.29532]$ & $-0.04856[0.14111]$ \\
\hline & 4 & $-0.509[0.582]$ & $0.62702[0.28332]$ & $0.20453[0.13459]$ & $0.67410[0.30586]$ & $-0.02818[0.14561]$ \\
\hline & 5 & $-0.175[0.591]$ & $0.25691[0.28715]$ & $0.11126[0.13605]$ & $0.67235[0.30918]$ & $-0.02086[0.14741]$ \\
\hline \multirow{4}{*}{ Material recycled content } & 2 & $0.541[0.455]$ & $-0.151[0.236]$ & $0.04749[0.10636]$ & $-0.054[0.237]$ & $0.09091[0.11055]$ \\
\hline & 3 & $-0.118[0.438]$ & $0.164[0.228]$ & $0.07663[0.10315]$ & $-0.032[0.229]$ & $0.07049[0.10661]$ \\
\hline & 4 & $-0.021[0.456]$ & $-0.166[0.238]$ & $0.01402[0.10678]$ & $0.25327[0.23743]$ & $0.05074[0.11054]$ \\
\hline & 5 & $0.513[0.482]$ & $-0.576[0.255]$ & $-0.023[0.111]$ & $0.06949[0.24855]$ & $0.03919[0.11614]$ \\
\hline \multirow{4}{*}{$\begin{array}{l}\text { Low environmental } \\
\text { impact }\end{array}$} & 2 & $0.58009[0.67482]$ & $-0.086[0.348]$ & $0.11865[0.15082]$ & $0.20821[0.35844]$ & $-0.26210[0.17546]$ \\
\hline & 3 & $0.67001[0.66046]$ & $0.241[0.341]$ & $0.07629[0.14792]$ & $0.22209[0.35180]$ & $-0.26502[0.17233]$ \\
\hline & 4 & $0.08993[0.67497]$ & $-0.205[0.349]$ & $005629[0.15053]$ & $0.38477[0.35792]$ & $-0.21093[0.17528]$ \\
\hline & 5 & $0.09049[0.68330]$ & $-0.458[0.355]$ & $0.04338[0.15199]$ & $0.33240[0.36146]$ & $-0.21603[0.17700]$ \\
\hline \multirow{3}{*}{$\begin{array}{l}\text { Fair working } \\
\text { conditions }\end{array}$} & 3 & $-0.660[1.364]$ & $0.02676[0.80478]$ & $0.38534[0.43935]$ & $0.40303[0.75335]$ & $0.04045[0.347171]$ \\
\hline & 4 & $-0.432[1.252]$ & $-0.884[0.733]$ & $0.42901[0.41477]$ & $0.27540[0.69538]$ & $0.11918[0.31921]$ \\
\hline & 5 & $-0.504[1.242]$ & $-0.594[0.729]$ & $0.42795[0.41344]$ & $0.24771[0.69109]$ & $0.09373[0.31710]$ \\
\hline \multirow{4}{*}{ Origin } & 2 & $-0.119[0.681]$ & $0.13977[0.35942]$ & $-0.020[0.152]$ & $0.06662[0.34587]$ & $-0.14223[0.16347]$ \\
\hline & 3 & $-0.090[0.583]$ & $0.24230[0.31070]$ & $0.04780[0.12910]$ & $0.08049[0.29634]$ & $-0.02972[0.14025]$ \\
\hline & 4 & $-0.049[0.590]$ & $0.20965[0.31405]$ & $0.01966[0.13096]$ & $0.05970[0.30002]$ & $-0.08928[0.14194]$ \\
\hline & 5 & $-0.197[0.619]$ & $0.15549[0.32986]$ & $0.02469[0.13715]$ & $0.01106[0.31525]$ & $0.02136[0.14928]$ \\
\hline
\end{tabular}

* Significant variables of each model per covariate are highlighted in grey. 
It is considered that socio-economic variable $X_{i}$ has a significant effect one response variable $\log \left[p_{k} / p_{1}\right]$ if the value of its corresponding regression coefficient $\beta_{i}$ is more than twice its standard deviation value. In addition, the positive sign of the corresponding $\beta_{i}$ implies that the response variable increases when the socio-economic variable increases. The higher the coefficient $\beta_{i}$, the stronger the effect of this socio-economic variable will be.

In general, only those coefficients associated with Repairability and one coefficient for Material recycled content are statistically significant, which means that only these two variables have a degree of influence on consumer decision to buy a product. With the aspect Repairability, socio-economic variable "household size" is significant for all the factors, with $\beta_{4}$ being positive in all cases. So the more people in a household, the more marked the tendency to repair products becomes. In addition, "age" is also significant, with older people being more prone to repair. For the aspect Recycled content material, it was found that the socio-economic variable "age" is statistically significant for respondents who consider the incorporation of material recycled content into the product design to be "very important". It can be said that, as $\beta_{2}$ is negative in this case, the younger the respondent is, the more importance attached to this aspect. For the remaining aspects, no significant relationship was found for any socio-economic variable.

Table 7 shows the results of the statistical models for the second response variable "Importance attached by consumers to including circular aspects on product labelling".

Table 7. Multinomial regression model for the "Importance attached by consumers to including circular aspects on product labelling" (mean [SD]).

\begin{tabular}{|c|c|c|c|c|c|c|}
\hline & & $\beta_{1}$ Gender & $\beta_{2}$ Age & $\begin{array}{c}\beta_{3} \text { Level of } \\
\text { Education }\end{array}$ & $\begin{array}{c}\beta_{4} \text { Household } \\
\text { Size }\end{array}$ & $\begin{array}{c}\beta_{4} \text { Household } \\
\text { Income }\end{array}$ \\
\hline \multirow{4}{*}{ Durability } & 2 & $0.23983[0.89660]$ & $0.10409[0.40905]$ & $0.21662[0.51988]$ & $-0.19842[0.44492]$ & $-0.01599[0.23766]$ \\
\hline & 3 & $0.50561[0.86894]$ & $0.27776[0.39406]$ & $0.21609[0.51988]$ & $-0.19085[0.43052]$ & $0.02367[0.2309]$ \\
\hline & 4 & $0.58897[0.87138]$ & $0.22653[0.39569]$ & $0.21511[0.51988]$ & $-0.05845[0.43147]$ & $0.02951[0.2314]$ \\
\hline & 5 & $0.60675[0.86499]$ & $0.04562[0.39198]$ & $0.21600[0.51898]$ & $-0.14634[0.42810]$ & $0.00689[0.22988]$ \\
\hline \multirow{4}{*}{ Repairability } & 2 & $-0.15649[0.47075]$ & $0.41050[0.24966]$ & $-0.00067[0.00127]$ & $0.15335[0.23752]$ & $0.03302[0.11770]$ \\
\hline & 3 & $-0.33728[0.46292]$ & $0.29361[0.24579]$ & $-0.00065[0.00123]$ & $0.13203[0.23345]$ & $0.08568[0.11585]$ \\
\hline & 4 & $-0.28644[0.48718]$ & $0.30134[0.25880]$ & $0.00025[0.00128]$ & $0.04187[0.24674]$ & $0.14865[0.12253]$ \\
\hline & 5 & $-0.24590[0.49039]$ & $0.03712[0.26478]$ & $-0.25266[0.18478]$ & $0.17020[0.24666]$ & $0.03570[0.12277]$ \\
\hline \multirow{4}{*}{$\begin{array}{l}\text { Material recycled } \\
\text { content }\end{array}$} & 2 & $1.50340[0.45961]$ & $-0.13006[0.19429]$ & $0.36097[0.23594]$ & $0.30423[0.23299]$ & $-0.06190[0.12165]$ \\
\hline & 3 & $0.89346[0.43044]$ & $0.06730[0.17585]$ & $0.36146[0.23594]$ & $0.19907[0.21927]$ & $-0.11212[0.11491]$ \\
\hline & 4 & $1.02471[0.44227]$ & $-0.15179[0.18398]$ & $0.36206[0.23595]$ & $0.32429[0.22478]$ & $-0.08269[0.11767]$ \\
\hline & 5 & $0.96939[0.45758]$ & $-0.30702[0.19530]$ & $0.36143[0.23595]$ & $0.36475[0.23192]$ & $-0.07842[0.12111]$ \\
\hline \multirow{4}{*}{$\begin{array}{c}\text { Low environmental } \\
\text { impact }\end{array}$} & 2 & $0.59060[0.57205]$ & $-0.14871[0.29318]$ & $0.00719[0.05036]$ & $0.11428[0.29639]$ & $0.03049[0.14274]$ \\
\hline & 3 & $0.59979[0.54433]$ & $0.08648[0.27802]$ & $0.00587[0.05036]$ & $0.11843[0.28246]$ & $-0.06577[0.13561]$ \\
\hline & 4 & $0.20878[0.55628]$ & $-0.15740[0.28509]$ & $0.00691[0.05036]$ & $0.26316[0.28787]$ & $0.11454[0.13866]$ \\
\hline & 5 & $0.36636[0.56922]$ & $-0.45147[0.29238]$ & $0.00657[0.05036]$ & $0.10232[0.29391]$ & $-0.05240[0.14161]$ \\
\hline \multirow{4}{*}{ Fair working conditions } & 2 & $21.83313[1.37761]$ & $-0.44589[1.01849]$ & $-4.92119[2.18041]$ & $-0.73443[1.68245]$ & $1.39259[0.98166]$ \\
\hline & 3 & $-26.62403[1.53908]$ & $0.73759[0.96700]$ & $-0.61355[0.39042]$ & $0.00718[0.91411]$ & $0.04282[0.52868]$ \\
\hline & 4 & $-26.62644[1.49994]$ & $0.25911[0.93001]$ & $-0.20867[0.19245]$ & $0.36800[0.87806]$ & $0.12630[0.51214]$ \\
\hline & 5 & $-26.83099[1.49526]$ & $0.60800[0.92554]$ & $0.00259[0.04185]$ & $0.33053[0.87476]$ & $0.09525[0.51052]$ \\
\hline \multirow{4}{*}{ Origin } & 2 & $0.01259[0.76867]$ & $0.14250[0.43926]$ & $-0.00248[0.63835]$ & $0.34450[0.39293]$ & $-0.07143[0.19719]$ \\
\hline & 3 & $0.09334[0.66308]$ & $0.29915[0.37646]$ & $0.58441[0.53467]$ & $0.18248[0.34116]$ & $0.00995[0.17059]$ \\
\hline & 4 & $0.09676[0.67134]$ & $0.29393[0.38025]$ & $0.58932[0.53461]$ & $0.17215[0.34532]$ & $-0.04883[0.17255]$ \\
\hline & 5 & $0.05360[0.70650]$ & $0.13501[0.40208]$ & $0.39117[0.58516]$ & $0.23085[0.36253]$ & $0.02897[0.18160]$ \\
\hline
\end{tabular}

* Significant variables of each model per covariate are highlighted in grey colour.

In general, only those coefficients associated with Material recycled content and Fair working conditions are statistically significant, which means that only those two variables have a degree of influence on a consumer decision to buy a product. For these two aspects, the socio-economic variable "gender" is significant for all cases, with $\beta_{1}$ being positive for all factors for the aspect Material recycled content and negative for the majority of factors for the aspect Fair working conditions. This means that males are more concerned about the aspect Material recycled content, while females are more concerned about the aspect Fair working conditions. In addition for the aspect Fair working conditions, the socio-economic variable "level of education" is significant for the respondents who attach "little importance" to including this aspect on product labelling. As $\beta_{3}$ is negative in this case, so the lower 
the level of education of respondents, the less importance attached to this aspect. For the remaining aspects, no significant relationship was found for any socio-economic variable.

\section{Discussion and Conclusions}

Consumer preferences for product purchases are increasingly influenced by factors associated with Durability, Repairability, Recycled material content or Low environmental impact, and with aspects related to Fair working conditions during production processes or Origin of production. They are all related with the principles promoted by a circular economy. In this study, we found that Spanish consumers are concerned mainly about fair working conditions during the production process and the durability of their purchased products.

For these two aspects, we found a high degree of congruence between the level of importance attached to incorporating each aspect into the product design process and including this information in product labelling. A contingency table analysis and the rejection of the independence between aspects in a product and aspects on labelling confirmed this finding. These results correspond to the marginal proportions for the aspects mentioned above.

In line with the findings of Park [26] about textile consumers, our results showed that socio-economic variables influence the level of importance attached to the social and environmental aspects considered in our study by consumers. By taking into account the importance attached to incorporating a certain aspect during the product design process, Repairability and Material recycled content have a degree of influence on consumer purchase decision. For the aspect Repairability, the more people in a household, the more marked the tendency to repair products. For the aspect Recycled content material, the younger respondents are, the more importance they attach to incorporating material recycled content into the product design. This contrasts with Pedrini's [39] findings, who considers that the most socially and environmentally concerned consumers are older, well-educated and wealthy. This discrepancy may be due to the different niche research markets [69].

By taking into account the importance attached to including a certain aspect in product labelling, males are more concerned about the aspect Material recycled content, while females are more concerned about the aspect Fair working conditions, as Hudson et al. [40] already pointed out. Finally, the lower the respondents' levels of education, the less importance they attach to the Fair working conditions aspect.

The research is not, however, without its limitations. Firstly, additional research is needed to confirm the study results because, according to Tucker [72], respondents tend to overemphasise the answers they give about their environmental behaviour when they feel that it might be judged or criticised by others. Secondly, the study did not consider the influence that some traditional aspects, such as price or quality, might have on consumer preferences in relation to social and environmental attributes. Consequently, a future in-depth study should be conducted that uses online and anonymous surveys to assess the more possible aspects preferred by consumers.

Thirdly, our findings are limited in scope as the sample only included Spanish consumers. Hence, more research in other countries is encouraged to identify whether consumer preferences related to product design and labelling are actually affected by different arrangements like cultural factors. So despite it not being clear if similar conditions to those in Spain prevail in other countries, our findings and results provide good insight into the trend that consumer preferences may follow in the mid and long terms. This may be considered valid for countries with similar cultural conditions, where the results may help to make new policies that focus and encourage socially and environmentally responsible purchases.

Author Contributions: Funding acquisition, M.-D.B.; Conceptualization and Methodology, M.-D.B., V.P.-B. and V.I.-F.; Statistical analysis, P.J. and C.D.-A.; Writing-Original Draft, M.-D.B. and V.P.-B.; Writing-Review and Editing, V.I.-F. and M.B.-G.

Funding: This research received funding from Ministerio de Economía y Competitividad (Spain) (Project DPI2017-89451-R). 
Conflicts of Interest: The authors declare no conflicts of interest

\section{References}

1. World Business Council of Sustainable Development (WBCSD). Sustainable Consumption Facts and Trends, from a Business Perspective. The Business Role Focus Area; World Business Council of Sustainable Development: Geneva, Switzerland, 2008.

2. The Ellen Macarthur Foundation. Towards the Circular Economy; The Ellen Macarthur Foundation: Cowes, UK, 2013.

3. Organisation for Economic Co-Operation and Development (OECD). Promoting Sustainable Consumption: Good Practices in OECD Countries; OECD: Paris, France, 2008.

4. COM 33 (2017) Implementation of the Circular Action Plan; Report from the Commission to the European Parliament, the Council, the European Economic and Social Committee and the Committee of the Regions. Available online: http:/ / ec.europa.eu/environment/circular-economy/implementation_report. pdf (accessed on 27 June 2018).

5. United Nations. Sustainable Development Goals: 17 Goals to Transform Our World. Available online: www.un.org/sustainabledevelopment/es/economic-growth/ (accessed on 27 June 2018).

6. Gurauskiene, I. The behaviour of consumers as one of the most important factors in e-waste problem. Environ. Res. Eng. Manag. 2008, 4, 56-65.

7. Guo, B.; Geng, Y.; Sterr, T.; Zhu, Q.; Liu, Y. Investigating public awareness on circular economy in western China: A case of Urumqi Midong. J. Clean. Prod. 2017, 142, 2177-2186. [CrossRef]

8. Braithwaite, N.; Densley-Tingley, D.; Moreno, M. Should energy labels for washing machines be expanded to include a durability rating? In Proceedings of the Product Lifetimes and the Environment (PLATE) Conference, Notthingham, UK, 17-19 June 2015.

9. Maurer, C.S.; Pachl, U. Durable Goods: More Sustainable Products, Better Consumer Rights; The European Consumer Organisation: Belgium, Brussels, 2015; Volume 32.

10. Nicholls, A.; Opal, C. Fair Trade: Market-Driven Ethical Consumption; Sage Publications: Thousand Oaks, CA, USA, 2005; ISBN 9781446211526.

11. Hertel, S.; Scruggs, L.; Heidkamp, C.P. Human Rights and Public Opinion: From Attitudes to Action. Polit. Sci. Q. 2009, 124, 443-459. [CrossRef]

12. Coelho, S.L. Fair trade consumers in Portugal: Values and lifestyles. Int. J. Consum. Stud. 2015, 39, 437-444. [CrossRef]

13. Spanish Circular Economy Strategy. Available online: http://www.mapama.gob.es/es/calidad-yevaluacion-ambiental/temas/economia-circular/estrategia/ (accessed on 27 June 2018).

14. Porter, A. How Long Should Your Washing Machine Last? Available online: https:// conversation.which.co. uk/home-energy/washing-machines-faulty-broken-lifespan-lifetime-warranty-guarantee/ (accessed on 27 June 2018).

15. De Pelsmacker, P.; Janssens, W. A model for fair trade buying behaviour: The role of perceived quantity and quality of information and of product-specific attitudes. J. Bus. Ethics 2007, 75, 361-380. [CrossRef]

16. European Commission. Europeans' Attitudes towards the Issue of Sustainable Consumption and Production. Available online: http:/ / ec.europa.eu/commfrontoffice/publicopinion/flash/fl_367_en.pdf (accessed on 27 June 2018).

17. European Economic and Social Committee. The Influence of Lifespan Labelling on Consumers; European Economic and Social Committee: Bruxelles, Belgium, 2016.

18. Dünnhoff, E.; Palm, A. Comprehensibility of the EU Energy Label. Results of Two Focus Groups and a Representative Consumer Survey; Ministry of Economic Affairs, Climate Protection, Energy and Regional Planning, Rhineland-Palatinate; European Union: Brussels, Belgium, 2014.

19. D'Souza, C. Bridging the communication gap: Dolphin-safe "ecolabels". Corp. Commun. Int. J. 2000, 5, 185-190. [CrossRef]

20. Grunert, K.G.; Hieke, S.; Wills, J. Sustainability labels on food products: Consumer motivation, understanding and use. Food Policy 2014, 44, 177-189. [CrossRef]

21. Schumacher, I. Ecolabeling, consumers' preferences and taxation. Ecol. Econ. 2010, 69, 2202-2212. [CrossRef] 
22. Saphores, J.D.M.; Ogunseitan, O.A.; Shapiro, A.A. Willingness to engage in a pro-environmental behavior: An analysis of e-waste recycling based on a national survey of U.S. households. Resour. Conserv. Recycl. 2012, 60, 49-63. [CrossRef]

23. Nixon, H.; Saphores, J.-D.M.; Ogunseitan, O.A.; Shapiro, A.A. Understanding preferences for recycling electronic waste in California: The influence of environmental attitudes and beliefs on willingness to pay. Environ. Behav. 2009, 41, 101-124. [CrossRef]

24. Saphores, J.D.M.; Nixon, H.; Ogunseitan, O.A.; Shapiro, A.A. Household willingness to recycle electronic waste: An application to California. Environ. Behav. 2006, 38, 183-208. [CrossRef]

25. Yang, Y.; Li, B.; Yao, R. A method of identifying and weighting indicators of energy efficiency assessment in Chinese residential buildings. Energy Policy 2010, 38, 7687-7697. [CrossRef]

26. Park, K.C. Understanding ethical consumers: Willingness-to-pay by moral cause. J. Consum. Mark. 2018, 35, 157-168. [CrossRef]

27. Rousseau, S. The role of organic and fair trade labels when choosing chocolate. Food Qual. Prefer. 2015, 44, 92-100. [CrossRef]

28. Panico, T.; Del Giudice, T.; Caracciolo, F. Quality dimensions and consumer preferences: A choice experiment in the Italian extra-virgin olive oil market. Agric. Econ. Rev. 2014, 15, 100-112.

29. Ladhari, R.; Tchetgna, N.M. Values, socially conscious behaviour and consumption emotions as predictors of Canadians' intent to buy fair trade products. Int. J. Consum. Stud. 2017, 41, 696-705. [CrossRef]

30. Coppola, A.; La Barbera, F.; Verneau, F. Fair trade products' consumption: A market segmentation by personal values. Qual.-Access Success 2015, 16, 23-31.

31. European Commission. Durability and the Construction Products Directive-Guidance Paper F-(Concerning the Construction Products Directive-89/106/EEC); Enterprise and Industry Directorate-General; European Commission: Brussels, Belgium, 2004.

32. Eco3e Ecodesign Guide of WEEE Compliance Schemes. Available online: http:/ /eco3e.eu/introduction_en/ (accessed on 10 January 2018).

33. European Commission. Directive 2012/19/EU of the European Parliament and of the Council of 4 July 2012 on Waste Electrical and Electronic Equipment (WEEE); European Commission: Brussels, Belgium, 2012.

34. International Organization for Standardization. Environmental Management. Life Cycle Assessment. Principles and Framework; ISO 14040; ISO: Geneva, Switzerland, 2006.

35. International Organization for Standardization. Environmental Management. Life Cycle Assessment. Requirements and Guidelines; ISO 14044; ISO: Geneva, Switzerland, 2006.

36. United Nations Environment Programme (UNEP-SETAC). The Methodological Sheets for Subcategories in Social Life Cycle Assessment (S-LCA); United Nations Environment Programme: Nairobi, Kenya, 2013.

37. Laureati, M.; Jabes, D.; Russo, V.; Pagliarini, E. Sustainability and organic production: How information influences consumer's expectation and preference for yogurt. Food Qual. Prefer. 2013, 30, 1-8. [CrossRef]

38. Cerri, J.; Testa, F.; Rizzi, F. The more I care, the less I will listen to you: How information, environmental concern and ethical production influence consumers' attitudes and the purchasing of sustainable products. J. Clean. Prod. 2018, 175, 343-353. [CrossRef]

39. Pedrini, M.; Ferri, L.M. Socio-demographical antecedents of responsible consumerism propensity. Int. J. Consum. Stud. 2014, 38, 127-138. [CrossRef]

40. Hudson, M.; Hudson, I.; Edgerton, J.D. Political consumerism in context: An experiment on status and information in ethical consumption decisions. Am. J. Econ. Sociol. 2013, 72, 1009-1037. [CrossRef]

41. Taylor, J.E.; Boasson, V. Who buys fair trade and why (or Why Not)? A random survey of households. J. Consum. Aff. 2014, 48, 418-430. [CrossRef]

42. D'Souza, C.; Taghian, M.; Lamb, P.; Peretiatko, R. Green decisions: Demographics and consumer understanding of environmental labels. Int. J. Consum. Stud. 2007, 31, 371-376. [CrossRef]

43. Kumar, A.; Holuszko, M.; Espinosa, D.C.R. E-waste: An overview on generation, collection, legislation and recycling practices. Resour. Conserv. Recycl. 2017, 122, 32-42. [CrossRef]

44. Sama, C.; Crespo-Cebada, E.; Díaz-Caro, C.; Escribano, M.; Mesías, F.J. Consumer Preferences for Foodstuffs Produced in a Socio-environmentally Responsible Manner: A Threat to Fair Trade Producers? Ecol. Econ. 2018, 150, 290-296. [CrossRef]

45. World Business Council for Sustainable Development. WBCSD Sustainable Procurement of Wood and Paper-Based Products; World Business Council for Sustainable Development: Geneva, Switzerland, 2011. 
46. The Nordic Consumer Ombudsmen. Nordic Consumer Ombudsmen. The Consumer Ombudsman's Guidelines on the Use of Environmental and Ethical Claims in Marketing; The Nordic Consumer Ombudsmen: Oslo, Norway, 2009.

47. Vehmas, K.; Raudaskoski, A.; Heikkilä, P.; Harlin, A.; Mensonen, A. Consumer attitudes and communication in circular fashion. J. Fash. Mark. Manag. Int. J. 2018. [CrossRef]

48. Hiller Connell, K.Y. Exploring consumers' perceptions of eco-conscious apparel acquisition behaviors. Soc. Responsib. J. 2011, 7, 61-73. [CrossRef]

49. Sarti, S.; Darnall, N.; Testa, F. Market segmentation of consumers based on their actual sustainability and health-related purchases. J. Clean. Prod. 2018, 192, 270-280. [CrossRef]

50. Panico, T.; Verneau, F.; Capone, V.; La Barbera, F.L.; Del Giudice, T. Antecedents of intention and behavior towards fair trade products: A study on values and attitudes in Italy. Int. J. Food Syst. Dyn. 2017, 8, 96-105. [CrossRef]

51. European Commission. Flash Eurobarometer 367 Attitudes of Europeans towards Building the Single Market for Green Products; European Commission: Brussels, Belgium, 2013; Volume 114.

52. Birch, D.; Memery, J.; De Silva Kanakaratne, M. The mindful consumer: Balancing egoistic and altruistic motivations to purchase local food. J. Retail. Consum. Serv. 2018, 40, 221-228. [CrossRef]

53. Van Loo, E.J.; Caputo, V.; Nayga, R.M.; Seo, H.S.; Zhang, B.; Verbeke, W. Sustainability labels on coffee: Consumer preferences, willingness-to-pay and visual attention to attributes. Ecol. Econ. 2015, 118, $215-225$. [CrossRef]

54. Grebitus, C.; Steiner, B.; Veeman, M.M. Paying for sustainability: A cross-cultural analysis of consumers' valuations of food and non-food products labeled for carbon and water footprints. J. Behav. Exp. Econ. 2016, 63, 50-58. [CrossRef]

55. Fabricio, A.C.B.; Da Veiga, C.P.; Marchetti, R.Z. Measuring consumer-oriented sustainability: A Brazilian perspective. Int. J. Environ. Sustain. Dev. 2017, 16, 257. [CrossRef]

56. De Carvalho, B.L.; Salgueiro, M.D.F.; Rita, P. Consumer sustainability consciousness: A five dimensional construct. Ecol. Indic. 2015, 58, 402-410. [CrossRef]

57. Department for Environment Food and Rural Affairs (Defra); Department of Trade and Industry (DTI). I Will If You Will. Towards Sustainable Consumption; Sustainable Development Commission: London, UK, 2006.

58. European Parliament. Directive 2009/125/EC of the European Parliament and of the Council of 21 October 2009 Establishing a Framework for the Setting of Ecodesign Requirements for Energy-Related Products. Available online: https:/ / eur-lex.europa.eu/legal-content/en/ALL/?uri=celex\%3A32009L0125 (accessed on 27 June 2018).

59. European Commission. Communication from the Commission to the European Parliament and the Council. Energy Efficiency and Its Contribution to Energy Security and the 2030 Framework for Climate and Energy Policy; European Commission: Brussels, Belgium, 2014.

60. Eurobarometer, F. Attitudes of Europeans towards Waste Management and Resource Efficiency. Available online: http:/ / ec.europa.eu/commfrontoffice/publicopinion/flash/fl_388_en.pdf (accessed on 27 June 2018).

61. Grankvist, G.; Biel, A. Predictors of purchase of eco-labelled food products: A panel study. Food Qual. Prefer. 2007, 18, 701-708. [CrossRef]

62. Koszewska, M. Social and eco-labelling of textile and clothing goods as a means of communication and product differentiation. Fibres Text. East. Eur. 2011, 87, 20-26.

63. Noblet, C.L.; Teisl, M.F.; Rubin, J. Factors affecting consumer assessment of eco-labeled vehicles. Transp. Res. D Transp. Environ. 2006, 11, 422-431. [CrossRef]

64. Pickett-Baker, J.; Ozaki, R. Pro-environmental products: Marketing influence on consumer purchase decision. J. Consum. Mark. 2008, 25, 281-293. [CrossRef]

65. Food Standards Australia New Zealand (FSANZ). Consumer Attitudes Survey 2007 Food. A Benchmark Survey of Consumer's Attitudes to Food Issues; FSANZ: Canberra, Australia, 2008; ISBN 978-0-642-34556-1.

66. Pérez-Belis, V.; Braulio-Gonzalo, M.; Juan, P.; Bovea, M.D. Consumer attitude towards the repair and the second-hand purchase of small household electrical and electronic equipment. A Spanish case study. J. Clean. Prod. 2017, 158, 261-275. [CrossRef] 
67. Bovea, M.D.; Ibáñez-Forés, V.; Pérez-Belis, V.; Juan, P. A survey on consumers' attitude towards storing and end of life strategies of small information and communication technology devices in Spain. Waste Manag. 2018, 71, 589-602. [CrossRef] [PubMed]

68. Bartlett, J.E.; Kotrlik, J.W.; Higgins, C.C. Organizational research: Determining appropriate sample size in survey research. Inf. Technol. Learn. Perform. J. 2001, 19, 43-50. [CrossRef]

69. Instituto Nacional De Estadistica (INE). Available online: http:/ / www.ine.es (accessed on 27 June 2018).

70. Agresti, A. Categorical Data Analysis; John Wiley \& Sons Inc.: Hoboken, NJ, USA, 2002; Volume 45, ISBN 0471360937.

71. Development Core Team R. R: A Language and Environment for Statistical Computing; 2011; Volume 1, ISBN 3900051070. Available online: http:/ / softlibre.unizar.es/manuales/aplicaciones/r/fullrefman.pdf (accessed on 27 June 2018.).

72. Tucker, P. Understanding Recycling Behaviour. Pap. Technol. 2001, 42, 51.

(c)

(C) 2018 by the authors. Licensee MDPI, Basel, Switzerland. This article is an open access article distributed under the terms and conditions of the Creative Commons Attribution (CC BY) license (http:/ / creativecommons.org/licenses/by/4.0/). 